\title{
Using local ecological knowledge to access the distribution of the Endangered Caatinga howler monkey (Alouatta ululata)
}

\author{
Robério Freire Filho1; Thieres Pinto2; Bruna Martins Bezerra ${ }^{1 *}$
}

\begin{abstract}
A lack of basic knowledge about the Endangered Caatinga howler monkey (Alouatta ululata) in Northeastern Brazil makes it difficult to design and implement effective conservation strategies. Traditional or Local Ecological Knowledge (LEK) has contributed to the development of conservation strategies for many species, including primates. Thus, we aimed to improve our understanding of the geographic range of Caatinga howler monkey, collect LEK on the species, and understand how people interact with these howlers to help future conservation efforts. We conducted semi-structured interviews with members of local communities in two regions within the currently known distribution range of the species. We constructed maps based on the information currently available in the literature and on the data obtained through our interviews. Through LEK, we identified new areas of occurrence for Caatinga howler monkeys, increasing the species' range in a Northeastern direction in the state of Ceará. Gross domestic product (GDP) and population size were inversely related to the amount of knowledge that the local human population showed about the Caatinga howler monkeys, indicating that local wealth influences in the amount of LEK. Despite a positive attitude towards Caatinga howler monkeys in both regions (i.e. howlers were not killed in retaliation for crop-feeding and locals found their vocalizations pleasant), we identified poaching and medicinal uses of the species. Our data demonstrated that the range of Caatinga howler monkeys was larger than previously recorded and also that local knowledge was crucial for triangulating the species location.
\end{abstract}

Keywords: Neotropical Primates; Ethnoprimatology; Occurrence areas; Local Community; Socioeconomic Profile; Conservation.

\footnotetext{
1 Programa de Pós-Graduação em Biologia Animal, Universidade Federal de Pernambuco, Centro de Biociências, Departamento de Zoologia. Av. Prof. Moraes Rego, 1235, Cidade Universitária. Cep. 50670-420. Recife-Pernambuco. Brasil.

2 Sertões Consultoria Ambiental e Assessoria, Rua Professor Carlos Lobo, 257, sala 02, CEP 60821-740, Parque Manibura, Fortaleza, Ceará, Brasil.

* freirefilho@outlook.com, Affiliation at the time of the data collection: Mestrado em Biologia da Conservação, Departamento de Biologia Animal, cE3c Centro de Ecologia, Evolução e Alterações Ambientais. Faculdade de Ciências, Universidade de Lisboa, Lisboa, Portugal.
}

\footnotetext{
*Corresponding author. $\mathrm{E}$ E-mail address: RFF (freirefilho@outlook.com), TB (thieres@sertoesconsutoria.com.br), BMB (brunamb1234@gmail.com)
} 


\section{INTRODUCTION}

The Caatinga howler monkey (Alouatta ululata) is a poorly known species endemic to Northeastern Brazil (Ferreira et al. 2016; Oliveira et al. 2007; Oliveira and Kierulff 2008). As with many primate species, Caatinga howler monkey populations are in decline due to hunting pressure, fragmentation and habitat loss (Ferreira et al. 2016; Oliveira et al. 2007; Oliveira and Kierulff 2008). In fact, based on data from interviews conducted with the local human population, Pinto and Roberto (2011) suggested that the main threats for Caatinga howler monkeys in Northern Piauí are hunting pressure $(51.8 \%$ of interviewees), followed by deforestation $(25.9 \%)$ and forest fires $(11.1 \%)$. Nevertheless, there is very limited information about the ecology, behavior, number of Caatinga howler monkey populations and their relation with local human communities (Oliveira and Kierulff 2008). This lack of information makes it difficult to design and implement effective plans for the conservation of the species. According to the Brazilian list of threatened fauna (Ferreira et al. 2016) and IUCN (Oliveira and Kierulff 2008), the Caatinga howler monkey is categorized as an Endangered species. Together with five other species, the Caatinga howler monkey now features in the second phase of the Brazilian Plan of Action for the Conservation of Primates in the Northeast (PANPriNE) of the country (Portaria $n^{\circ} 242$, de 26 de março de 2018). Caatinga howler monkeys are characterized by their vocalizations. They are a folivore-frugivore species and have a diet composed of at least 23 plant species (Pinto and Roberto 2011). The species' home range varies between 13.85 ha and 35.62 ha (depending on the estimation method and type of vegetation) and groups are small, ranging in size from 8-10 individuals (Pinto and Roberto 2011). The taxonomic status of the Caatinga howler monkey is still under debate, with some suggesting that it is a subspecies of redhanded-howler monkeys, Alouatta belzebul (see Gregorin 2006; Viana et al. 2015). Here we follow Gregorin (2006) and consider Caatinga howler monkeys as a separate species from red-handed-howler monkeys. Caatinga howler monkeys occur in one of the poorest regions of Brazil (Leal et al. 2005; Veiga et al. 2004), and they are distributed across three states: Maranhão (north), Piauí (north and north central) and Ceará (northwest) (Ferreira et al. 2016; Oliveira et al. 2007; Oliveira and Kierulff 2008).

The increase in human populations and rapid expansion of urban areas have led to widespread primate population declines, mostly due to habitat fragmentation and hunting pressure (Fuentes and Hockings 2010; Stafford et al. 2016; Torres Junior et al. 2016). To minimize the negative effects of interactions between human and non-human primates, it is essential to understand the core nature of such interactions (Fuentes 2006). Humans and non-human primates have interacted in many ways for a long time, with positive and negative implications for both parties, and these interactions vary historically and culturally (Ceballos-Mago and Chivers 2010; Dore et al. 2017; Fuentes 2006; Fuentes and Hockings 2010; Stafford et al. 2016). Understanding such interactions is an important tool for primate conservation due to the influence of human development on primate habitats (Fuentes and Hockings 2010). Thus, understanding the context and details of relationships between humans and other primates can help significantly in the attempt to find solutions for the conservation of primates (Estrada 2006; Fuentes et al. 
2016). Ethnoprimatology analyzes these relationships between humans and nonhuman primates (Dore et al. 2017; Fuentes and Hockings 2010; Hill and Webber 2010; Riley 2006; Stafford et al. 2016).

Investigations on Traditional or Local Ecological Knowledge (LEK) helps to further increase the understanding of the relationship between primates, non-human primates and their sometimes shared environment (Torres Junior et al. 2016). LEK basically describes local human communities' accumulated knowledge of their natural environment (Toledo 2002). It is based on their extensive contact with nature, and is passed on and modified across generations through cultural transmission (Gadgil et al. 1993; Silvano et al. 2008; Torres Junior et al. 2016). Studies of LEK have provided new and important information for science (Alves et al. 2016; Ceballos-Mago and Chivers 2010; Davis and Wagner 2003; Gilchrist et al. 2005; Silvano et al. 2008; Torres Junior et al. 2016), contributing to the development of management and conservation strategies in many fields (Gilchrist et al. 2005; Gray et al. 2017; Haenn et al. 2014; Olsson and Folke 2001; Pandey 2003; Riedlinger and Berkes 2001). For instance, Gray et al. (2017) used LEK from fishing communities to monitor the hunting of rare fish species. Gilchrist et al. (2005) found LEK to be a useful source of information to help with management and conservation strategies for three out of four marine birds. Nevertheless, they also suggest that the use of LEK should be applied together with scientific studies to reliably implement management decisions. LEK can help in obtaining new information on the presence or qualitative abundance of species (Alves et al. 2016; Anadón et al. 2009; Anadón et al. 2010; Moller et al. 2004; Starr et al. 2011; Vaughan et al. 2003). This approach can provide high-quality and lowcost information (Anadón et al. 2010) to researchers about species' ranges. Data on the occurrence of poorly known species are essential to establish conservation planning at a regional scale (Rondinini et al. 2006) and habitat extent is one of the most important pieces of information when assessing the conservation status of species (Burgman and Fox 2003; Lunney et al. 1995). Several species on the IUCN red list have limited or no data at all on their distribution and thus, LEK could be used as a potential tool to obtain such information (Castellanos-Galindo et al. 2011). McPherson et al. (2016), for example, used local knowledge to obtain information on the distribution and habitat needs of Tragelaphus spekii gratus. Newton et al. (2008) used semi-structured interviews with hunters and museum reports to produce the first distribution maps for the pangolins Manis pentadactyla and $M$. javanica in Vietnam. Moreover, local knowledge has already been used as a tool for testing the validity of predictive models aiming to assess mammalian spatial distribution and to identify local species richness patterns (López-Arévalo et al. 2011).

LEK and cultural traditions are increasingly threatened by changes in land use, urbanization and modernization of public services such as education systems and globalization processes (Pilgrim et al. 2008; Gomez-Baggethun et al. 2013). The degradation of LEK can have negative implications for the status of the biodiversity (Tang and Gavin 2016), where low levels are decisive for the conservation of biodiversity, mainly in regions where hunting pressure is high (Petry and Smith 2004; Pilgrim et al. 2008). Gross Domestic Product (GDP), charcoal production and human population size can indicate community wealth and 
urbanization levels in rural and indigenous areas and may help to estimate patterns of LEK (Czech and Pister 2005; CullenUnsworth et al. 2007; Cullen et al. 2007; Pilgrim et al. 2008; Aswani et al. 2018). Studies have shown, for instance, that there is an inverse relationship between local marine ecological knowledge and wealth (Cullen et al. 2007). Furthermore, industrialized communities have less knowledge of species names and uses than nature resource-dependent communities (Pilgrim et al. 2008). Knowledge levels can differ between individuals of different ages and tend to be concentrated in a small group of people (Pilgrim et al. 2008; Aswani et al. 2018). This suggests that knowledge of species names, for instance, becomes concentrated in fewer people who have personal interests (e.g., environmental students) in wealthier industrialized communities. In contrast, knowledge of species names and uses in resourcedependent communities are likely to be shared among all community members engaged in the daily tasks that meet their family's needs (Pilgrim et al. 2008).

This study focused on two regions within the known distribution area of the Caatinga howler monkeys in the Caatinga Bioma in Northeastern Brazil to address the following questions: 1) Could LEK provide new reports of the presence of Caatinga monkeys in unknown areas? 2) Do social (i.e. population size), economic (i.e. GDP and Charcoal production) and landscape characteristics influence both LEK and the relation between local communities and the Caatinga howler monkeys? In this study, we intended to improve our understanding of the geographic range of the Caatinga howler monkey, obtain LEK of the species and understand how people interact with it to help future conservation efforts.

\section{MATERIAL AND METHODS}

\section{Study area}

We carried out the study in two regions with different geography, environments and cultures. Both sites are in the Caatinga biome and have a semi-arid climate (Alvares et al. 2013; Moro et al. 2016). We selected two specific regions (i.e. Ceará and Piauí regions detailed below) within the range of the currently known distribution area for Caatinga howler monkeys. Primate species inhabiting both areas are: Alouatta ululata, Callithrix jacchus (common marmoset) and Sapajus libidinosus (bearded capuchin) (Bicca-Marques et al. 2006; Oliveira and Kierulff 2008). The spoken language in both areas is Portuguese with little variation in local accent. The investigated regions were:

1) Ceará Region is in the Northwestern area of the state of Ceará, Brazil, and includes several towns in the municipalities of Santana do Acaraú and Ibiapaba Mountain (Figure 1). Much of Ceará region is in two protected areas: Serra da Ibiapaba Environmental Protection Area $(1,628,424.61$ ha) and Serra da Meruoca Environmental Protection Area (29,361.27 ha, Drummond et al. 2009; MMA 2016). The area is composed of humid forest enclaves, with high altitudes $(750-900 \mathrm{~m})$, steep slopes, high rainfall (the annual mean above $1,100 \mathrm{~mm})$, low temperatures $\left(24-26^{\circ} \mathrm{C}\right)$ and good conditions for agriculture (Souza and Oliveira 2006; Tabarelli and Santos 2004). Livestock raising is an uncommon activity in the humid enclaves but local people raise animals in captivity (Souza and Oliveira 2006). Agriculture is the main activity in these regions, horticulture, coffee, rice and sugarcane plantations (Souza and Oliveira 2006). The steep nature of the area limits the sugarcane industry (Souza and 
Oliveira 2006). Tourism is an important activity in the area (e.g., hiking at Ibiapaba Mountain). The local community is mainly composed of cultivators and rural workers.

2) Piauí Region is in the North-central area of the state of Piauí, and includes several towns in the municipalities of Castelo do Piauí and Valença do Piauí (Figure 1). Piauí region has one protected area (Marvão Private Natural Heritage Reserve) with 5,096.86ha. In contrast to Ceará region, most of Piauí region is unprotected (Drummond et al. 2009; MMA 2016). The area has high annual mean temperatures $\left(28-30^{\circ} \mathrm{C}\right)$, low humidity $(60-65 \%)$, high evapotranspiration (1400-1550 mm), high evaporation (2000-2500 mm), and low and irregular precipitation (annual mean 800$1000 \mathrm{~mm}$ ) (Andrade Júnior et al. 2004; Gomes et al. 2005). The region has large areas of semideciduous trees and dry forest areas and some parts have typical Cerrado forest features (pers. obs.). Livestock farming is the main activity in the area, focused mainly on goats and cattle. Farmers ("vaqueiros") raise animals free-range in the Caatinga forest. Agriculture is also present in the region, but on a smaller scale when compared to livestock.

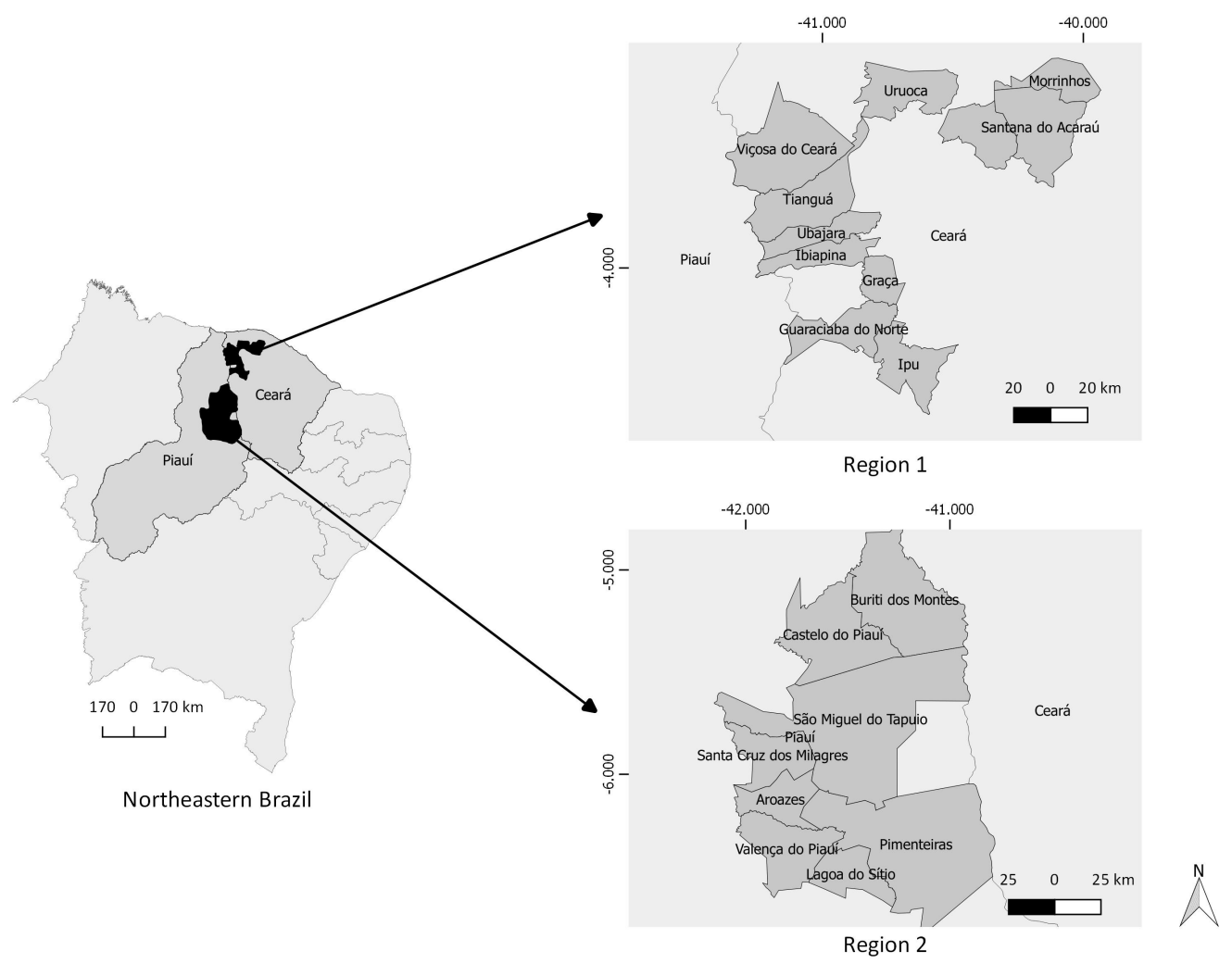

Figure 1. Areas surveyed for the presence of the species and LEK in Ceará and Piauí regions in the states of Ceará and Piauí, respectively, in North-eastern Brazil. We conducted interviews in all the named municipalities in August 2016 in Ceará region and in January 2017 in Piauí region. 


\section{Survey Methods}

First, we conducted two 10-day expeditions to perform semi-structured interviews (Huntington 2000). RRF conducted the interviews in Portuguese, often accompanied by a field assistant, in August 2016 in the Ceará Region and in January 2017 in Piauí Region. A third 10-day field expedition was conducted in May 2017 to confirm the presence of the species in the areas where new presence reports were obtained during the first two expeditions. For logistical reasons, we were limited to 10-day expeditions.

We conducted 50 interviews in the Ceará Region. Between the municipalities of Santana do Acaraú and Ibiapaba Moutain in the state of Ceará, we drove approximately $650 \mathrm{~km}$, crossing 11 municipalities (Figure 1). In the Piauí region, we conducted 62 interviews. Between the municipalities of Castelo do Piauí and Valença do Piauí, in the state of Piauí, we drove approximately $700 \mathrm{~km}$ crossing eight municipalities (Figure 1).

Each interview lasted approximately 20 minutes however, when we met people who knew about the Caatinga howler monkeys, we spent an extra 10-20 min with them. In our interviews, we targeted local men and women who used the forest for some sort of activity (e.g., farmers, cultivators and hunters) and/or who lived close to areas with natural vegetation, and who were 18 years old or older. We approached interviewees on local roads near areas with natural vegetation where there was a potentially suitable habitat for the Caatinga howler monkeys, to avoid concentrating the interviews in a specific place. Thus, we preestablished a minimum number of 50 interviews per region due to the expected low number of people on the road in such condition. Here we used the terms "local community" and "local people" as synonyms, when referring to the people living in small villages (i.e. clusters of houses) in the rural area of the visited counties. All interviewees were long-term residents (i.e. they had been living in the area since childhood or were born in the area).

We started interviews as an informal conversation with the interviewees, seeking to gain their trust first, then inquiring about their knowledge of local wildlife. We always asked for consent before beginning an interview. We explained that participation in our study was voluntary and that the interviewee could withdraw at any time if they wished to do so. We explained that all interviews were anonymous and they would not be at any risk in answering the questions. We also explained the benefits of the study for the conservation of animals in general and only proceeded with the interview if the person agreed and was comfortable with the situation. At the end of the interviews we always informed the interviewees that we were carrying out research in the region to specifically learn about the distribution of the Caatinga howler monkey. We avoided giving this information prior to the beginning of the interview so that we did not influence the responses of the interviewees. The present study agrees with the The Ethical Code Developed by British Sociological Association to conduct the interviews (https://www.britsoc.co.uk/media/24310/bsa statement_of_ethical_practice.pdf). The study was endorsed by the MSc Programme in Conservation Biology, Faculty of Sciences; Lisbon University, Portugal (Mestrado em Biologia da Conservação, Departamento de Biologia Animal, cE3c Centro de Ecologia, Evolução e Alterações Ambientais. Faculdade de Ciências, Universidade de Lisboa, Lisboa, Portugal). 
We began interviews with some general questions about the mammals that can be found in the region, other than the Caatinga howler monkey, for example: collared peccaries (Pecari tajacu), pumas (Puma concolor), lowland pacas (Cuniculus paca), capybaras (Hydrochoerus hydrochaeris) and deer (Mazama sp.). We aimed to determine how knowledgeable the interviewee was about the local fauna. After this initial approach, we asked questions about the common marmoset (Callithrix jacchus) and the bearded capuchin (Sapajus libidinosus) and finally about the Caatinga howler monkey. We asked the interviewees to describe the animal and its vocalization to confirm whether they were familiar with the species. We also asked the same questions using different wording to check whether the information provided by the respondents was consistent. Once the interviewee confirmed the presence of the Caatinga howler monkey in the region or showed that they knew of the species, we asked: (1) When was the last time you saw the Caatinga howler monkey? (2) How often do you hear the vocalization (e.g., always, seasonal or infrequent)? (3) How many animals did you see in the group? (4) Have Caatinga howler monkeys always existed in the region? (5) Have Caatinga howler monkey populations declined or increased? (6) Do people hunt the Caatinga howler monkey? (7) Do people eat Caatinga howler monkey here? (8) Where do Caatinga howler monkeys live? and (9) What do Caatinga howler monkeys eat? Some of the questions were aimed at elucidating the species biology (e.g., knowledge on vocalization and diet patterns) to help guiding future studies.

\section{Mapping Caatinga howler monkey distribution}

To compile and expand the distribution areas for Caatinga howler monkeys, we mapped the distribution of the species based on the information currently available in the literature (Bonvicino et al. 1989; Ferreira et al. 2016; Gregorin 2006; Gutiérrez and Marinho-Filho 2017; Oliveira et al. 2007; Oliveira and Kierulff 2008; Viana et al. 2015); and the new reports and records we obtained in the expeditions conducted in the present study. We used QGIS 2.8 software (QGIS Development Team 2016) to construct the maps.

\section{Statistical Analysis}

Data on Gross Domestic Product (GDP), human population size and charcoal production of the municipalities in both regions were obtained through the Brazilian Institute of Geography and Statistics. We used Mann-Whitney $U$ tests to verify whether the two regions differed significantly in these aspects. Finally, we use descriptive statistics to provide the information obtained from the interviewees about their ecological knowledge and interaction with Caatinga howler monkeys.

\section{RESULTS}

\section{Distribution of the Caatinga howler monkey}

We obtained 17 reports of the presence of the Caatinga howler monkey in Ceará region. We obtained historical and current reports in Auiá $\left(-3.449481^{\circ} ;-40.476306^{\circ}\right)$, a set of enclaves which are new occurrence areas for Caatinga howler monkeys, 
increasing the species' range in a northeastern direction in Ceará State (Figure 2 ). We obtained 10 reports of the presence of the species in this area, and recorded the species vocalization during a further expedition in the same area in May 2017. This signifies an expansion of approximately $6,133 \mathrm{~km}^{2}$ of the known species range $(\sim 3 \%)$. From our interviews, we also obtained seven reports on the eastern slope of Ibiapaba Mountain (Figure 2).

We obtained no reports of Caatinga howler monkeys in the enclaves to the east of Aiuá and saw no evidence of a suitable habitat for Caatinga howler monkeys in the area. However, it is possible that there are more undiscovered Caatinga howler monkey populations further south of Piauí, overlapping with the distribution of the black- and-gold howler monkey (Alouatta caraya). The western limit of the species' range is still uncertain due to overlapping with the distribution of the red-handed howler monkey (Alouatta belzebul).

We obtained 35 reports of the presence of the Caatinga howler monkey and one direct observation in Piauí region. We obtained reports of the presence of the species in all the municipalities we visited, except Buriti dos Montes (Figure 3). We observed a group of approximately eight individuals, including two infants in the Cágados area, and we heard three more groups vocalizing in the same area. We also identified four potential study sites in privately owned areas where Caatinga howler monkey groups could be monitored in the future (Figure 3).

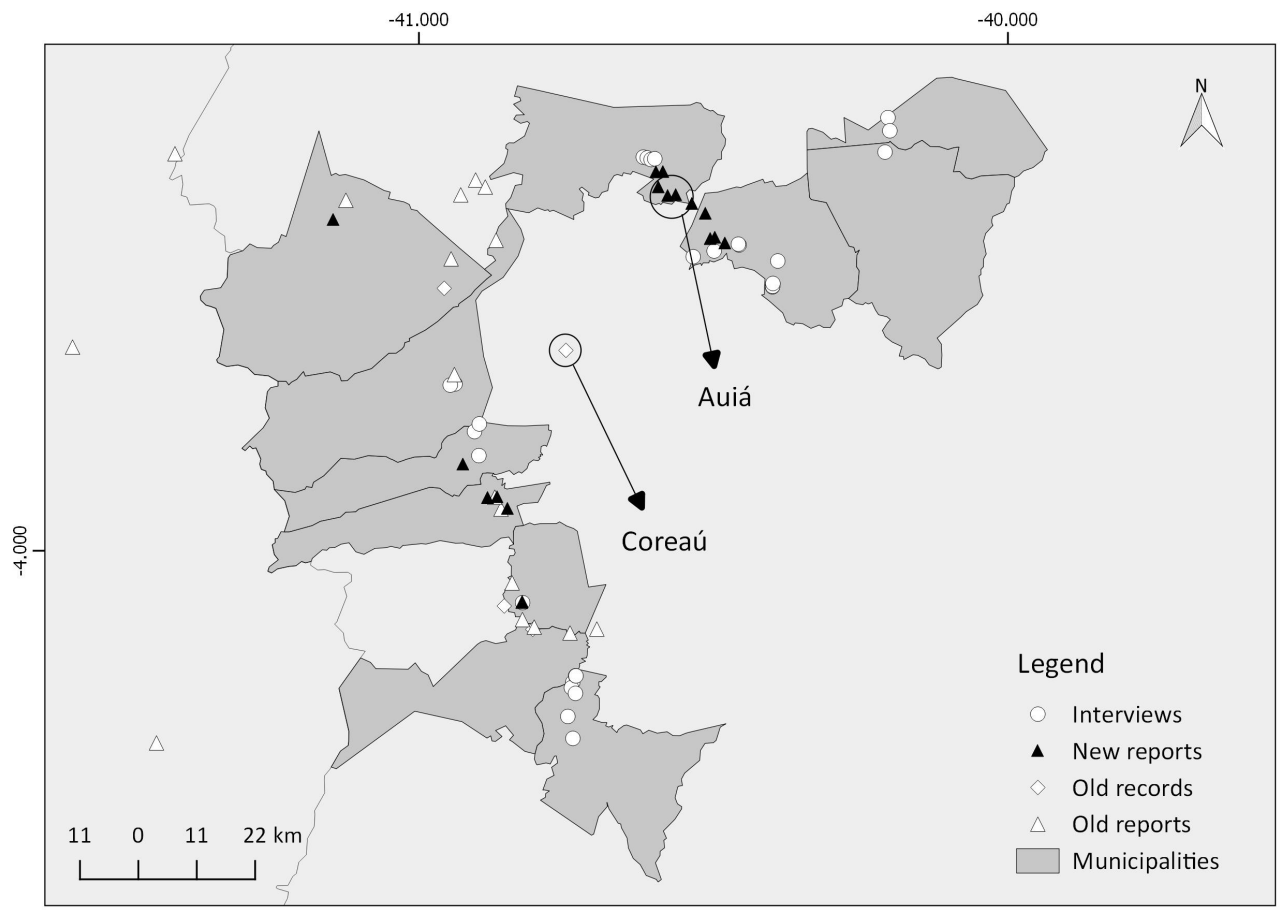

Figure 2. Localization of the municipalities surveyed in the Ceará region, state of Ceará, Northeastern Brazil, highlighting the new reports (LEK reports), previous records and previous reports of the Caatinga howler monkey presence in the region. The area was surveyed in August 2016. 


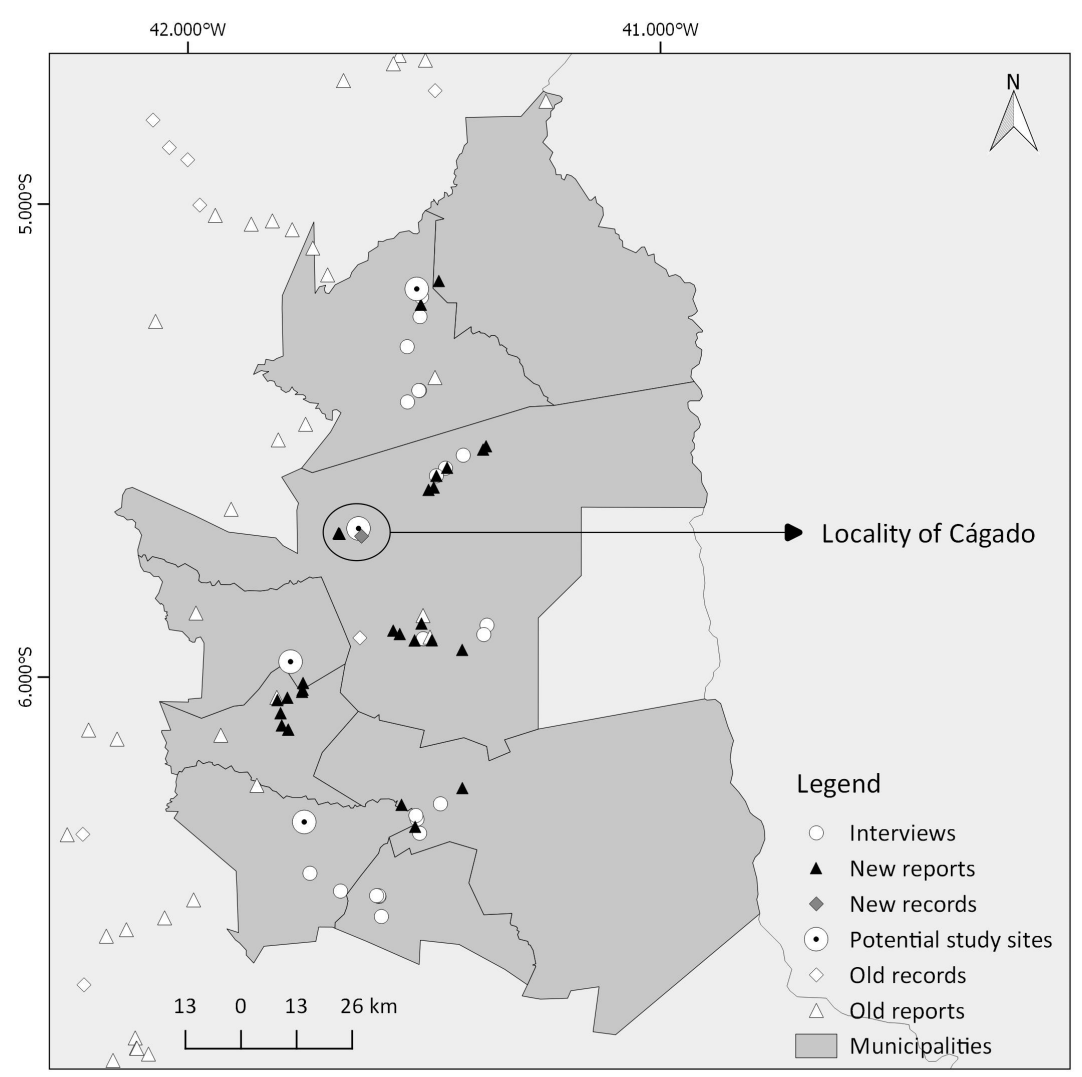

Figure 3. Localization of the municipalities surveyed in the Piauí region, state of Piauí, Northeastern Brazil, highlighting the new reports (LEK reports), previous records and previous reports of the Caatinga howler monkey presence in the region. The area was surveyed in January 2017.

\section{Profiles of the communities in the Ceará and Piauí region}

The Ceará region had a larger resident population than the Piauí region (MannWhitney, U=2.849, N1=11, N2=8, $\mathrm{p}<0.01$ ). Even though The Ceará region had a greater total GDP (sum of the GDP of each municipality in 2014) $(74,164)$ than the Piaui region $(51,311)$, there was no significant difference between the GDP of Ceará and Piauí regions when we considered the municipalities separately (Mann-Whitney, $\mathrm{U}=1.073, \mathrm{~N} 1=11, \mathrm{~N} 2=8, \mathrm{p}=0.32$ ). In both regions, the GDP increased every year between 2010 and 2014. Overall, charcoal production was five times higher in the Piaui region than in the Ceará region in 2014 $(3,132 \mathrm{t}$ and $480 \mathrm{t}$, respectively) and 2015 $(2,773 \mathrm{t}$ and $500 \mathrm{t}$, respectively), but we found no significant differences for the year 2014 (Mann-Whitney, $\mathrm{U}=0.908, \mathrm{~N} 1=11$, $\mathrm{N} 2=8, \mathrm{p}=0.36$ ) or in 2015 (Mann-Whitney, $\mathrm{U}=0.578, \mathrm{~N} 1=11, \mathrm{~N} 2=8, \mathrm{p}=0.56$ ) when we considered the municipalities separately.

In the Ceará region, $4 \%$ of interviewees were female and $96 \%$ were male. In the Piauí region, $11 \%$ of interviewees were female and $89 \%$ were male. The larger number of males in both areas could be a reflection of the method carried out to approach the interviewees (i.e. we 
approached them on local roads near areas with natural vegetation where men can be more easily found than women in both areas). In these communities, women traditionally stay at home making food and organizing the house. Men stay away from home for much of the day, working in agriculture or with livestock.

\section{Local Ecological knowledge of the Caatinga howler monkey}

We observed differences in the level of LEK according to economic (i.e. charcoal production and GDP), social (human population size) and environmental (type of vegetation and topography) characteristics of the regions.

Based on our observations and interviews, in the Ceará region, Caatinga howler monkey groups were in humid enclave areas but they were mainly restricted to areas with steep slopes. In Piauí region, Caatinga howler monkey groups inhabited flat areas with arboreal Caatinga (a mix of carrasco vegetation and Cerrado) and in canyons (valleys that hold a water source, with tall green plants). Caatinga howler monkey populations usually inhabited locations far from urban areas.

In the Ceará region, nearly half of the interviewees knew about Caatinga howler monkeys (Table 1). These people were long term residents in the area and lived very close to Caatinga howler monkey groups. In the Aiuá area and Ibiapaba Mountain, interviewees reported that Caatinga howler monkeys live in the mountains of the region, feed mostly on leaves and fruits, howl early in the morning or late in the afternoon and more often during the rainy season (period of February to June). Local people also said that they believe that Caatinga howler monkey populations have declined and that poaching still occurs in the region (Table 1). An 80-year-old man from the Uruoca municipality reported that major droughts in previous years (i.e., 1958) were important events for the local extinction of several medium and large sized mammal populations. He explained that the lack of water and food for the region's fauna, and hunting, were responsible for these extinctions. The local community, faced with the scarcity of natural resources during the drought, used the wild animals as a source of food more frequently.

In both regions, Caatinga howler monkeys are popularly known as Guariba or Capelão. However, the proportion of people who knew about Caatinga howler monkeys was much greater in the Piauí region than in the Ceará region (Table 1). Interviewees in the Piauí region reported that: Caatinga howler monkey populations live in canyon areas and in arboreal Caatinga areas far from urban areas, feed on leaves and fruits and also on some cultivated fruits such as mango (Mangifera indica L.), guava (Psidium guajava L.), cashew (Anacardium occidentale L.), custard apple (Annona squamosa L.); They also said that the monkeys howl in the early morning or late afternoon and more frequently during the pre-rainy season (November to January), when the cashew is fruiting or on the rainy season (February to June). Local people also said that Caatinga howler monkey populations have declined and that they believe that poaching still occurs in the region. Some interviewees in the Piauí region $(18 \%)$ also reported that eating Caatinga howler monkeys would be like eating other humans, suggesting they did not appreciate performing such behavior (Table 1). 
We obtained reports of the use of Tapuio (i.e. Cágados and Palmeira) and in Caatinga howler monkeys for medicinal one area in Valença do Piauí (i.e. Retiro). In purposes in two areas in São Miguel do the Cágados area, where we recorded four

Table 1. Summary of Local Ecological Knowledge (LEK) of the Caatinga howler monkeys in Regions Ceará and Piauí in the states of Ceará and Piauí in Northeastern Brazil, during August 2016 and January 2017, respectively. *Responses are not mutually exclusive, which means they can overlap one another .

\begin{tabular}{|c|c|c|c|}
\hline \multirow[t]{2}{*}{ Question } & \multirow[t]{2}{*}{ Given responses } & \multicolumn{2}{|c|}{$\begin{array}{l}\text { Percentages of interviewees that } \\
\text { gave each response in: }\end{array}$} \\
\hline & & Ceará region & Piauí region \\
\hline \multirow{2}{*}{$\begin{array}{l}\text { Do you know of } \\
\text { the Caatinga } \\
\text { howler monkeys? }\end{array}$} & Yes & $44 \%$ & $92 \%$ \\
\hline & No & $56 \%$ & $8 \%$ \\
\hline \multirow{3}{*}{$\begin{array}{l}\text { Where do } \\
\text { Caatinga howler } \\
\text { monkeys live? }\end{array}$} & Mountains & $100 \%$ & $0 \%$ \\
\hline & $\begin{array}{l}\text { Canyon areas and in arboreal } \\
\text { Caatinga }\end{array}$ & $0 \%$ & $91 \%$ \\
\hline & I don't know & $0 \%$ & $9 \%$ \\
\hline \multirow{4}{*}{$\begin{array}{l}\text { When do } \\
\text { Caatinga howler } \\
\text { monkeys } \\
\text { vocalize? * }\end{array}$} & $\begin{array}{l}\text { Early hours of the morning or } \\
\text { late hours of the afternoon }\end{array}$ & $53 \%$ & $51 \%$ \\
\hline & $\begin{array}{l}\text { Rainy season (i.e. February } \\
\text { to June) }\end{array}$ & $53 \%$ & $15 \%$ \\
\hline & $\begin{array}{l}\text { Pre-rainy season (period of } \\
\text { November to January) and } \\
\text { the fruiting of the cashew }\end{array}$ & $0 \%$ & $11 \%$ \\
\hline & I don't know & $47 \%$ & $49 \%$ \\
\hline \multirow{3}{*}{$\begin{array}{l}\text { What do Caatinga } \\
\text { howler monkeys } \\
\text { eat? * }\end{array}$} & Leaves and fruits & $41 \%$ & $48 \%$ \\
\hline & Cultivated fruits & $0 \%$ & $34 \%$ \\
\hline & I don't know & $59 \%$ & $52 \%$ \\
\hline \multirow{3}{*}{$\begin{array}{l}\text { Did Caatinga } \\
\text { howler monkeys } \\
\text { population } \\
\text { decline? }\end{array}$} & Yes & $47 \%$ & $25 \%$ \\
\hline & No & $0 \%$ & $0 \%$ \\
\hline & I don't know & $53 \%$ & $75 \%$ \\
\hline \multirow{3}{*}{$\begin{array}{l}\text { Does poaching } \\
\text { occur in the } \\
\text { area? }\end{array}$} & Yes & $47 \%$ & $43 \%$ \\
\hline & No & $53 \%$ & $57 \%$ \\
\hline & I don't know & $0 \%$ & $0 \%$ \\
\hline
\end{tabular}


groups of Caatinga howler monkeys, five locals reported that Caatinga howler monkeys are often found dead during the dry season, potentially due to lack of food and/or water. They also reported that during the wettest period of the year, Caatinga howler monkeys howl at night (about until eight o'clock). Three men that lived in Cágados reported that the howler monkey bosses of social groups (i.e. the alpha or dominant male) performed most of the reproductive and protection behavior. They also reported that these type of males usually played around the group vocalizing loudly and often defecated together at the same time.

The Caatinga howler monkey vocalizations were often mentioned by the interviewees, confirming the peculiar characteristic of Alouatta species (i.e. production of very loud howls that can be easily identified). In both regions, the interviewees reported that they usually do not see the animals, but often listen to their vocalizations. The locals reported that during the wettest period of the year, Caatinga howler monkeys are seen and heard more frequently. Moreover, they reported that during the driest period of the year, Caatinga howler monkeys howl more infrequently. Some people, in both regions, reported that Caatinga howler monkeys' vocalizations are similar to the noise produced by the old sugar cane mill moved by animal traction. All interviewees said that Caatinga howler monkeys live in small groups (between three and eight animals) or alone. Direct observations and recording of the vocalizations of the Caatinga howler monkeys would be important to confirm such information passed on by the local community and to further investigate the communication system of the species.

\section{Relationship between local human communities and Caatinga howler monkeys}

The relationship between the local community and the study species was found to be similar in both study regions, with no conflicts between them. In general, the local people treated Caatinga howler monkeys with relative indifference, keeping a neutral or positive relationship with the animals. Even when Caatinga howler monkeys feed on fruits that are consumed by the local people (e.g., mango, cashew and guava), they do not seem to have negative perceptions of the monkeys. Nevertheless, there were reports of poaching and medicinal use of the species in three areas (i.e. Cágados, Palmeira and Retiro as reported above). Their meat is not a frequent component of people's diets, but it is regarded as a delicacy, tasty and peculiar. $33 \%$ of the local people we interviewed reported that they enjoyed the vocalizations produced by Caatinga howler monkeys and $15 \%$ believed that such vocalizations could announce or attract the rains, which was good for agriculture. In contrast, interviewees reported that Caatinga capuchin monkeys, Sapajus libidinosus, are involved in negative interactions with the local communities (i.e. retaliation) in both study regions, because the capuchins forage crops and orchards $(63.6 \%$ of the areas we visited in Ceará region and $87.5 \%$ in Piauí region; seven municipalities in each region).

\section{DISCUSSION}

Our study extends the known range of the Caatinga howler monkey and shows that local knowledge is useful in understanding the distribution of these primates. Based on the compilation of data currently available 
and data we collected, we found that the distribution area of Caatinga howler monkeys incorporates the Ibiapaba mountain micro-region, the Coreaú microregion and the area of Aiuá (the eastern limit of the range) in the northwestern area of the state of Ceará (Bonvicino et al. 1989; Gregorin 2006; Guedes et al. 2000; Gutiérrez and Marinho-Filho 2017; Oliveira et al. 2007; Oliveira and Kierulff 2008; Viana et al. 2015). The east slopes of the Ibiapaba Mountain (an area that is very steep with natural vegetation) house a large proportion of the Caatinga howler monkeys population in Ceará (Oliveira et al. 2007). Moreover, Oliveira et al. (2007) detected Caatinga howler monkeys in Coreaú city in Ceará state through vocalizations. This was the easternmost distribution point for the species. However, despite few reports in Ceará region, we registered Caatinga howler monkeys around Auiá (approximately 34 km east of Coreaú city). It is difficult to know if there are more Caatinga howler monkey populations in the northeastern area of its range because, like other researchers (Oliveira et al. 2007), we did not observe the species. Nevertheless, our results show an expansion of $6,133 \mathrm{~km}^{2}$ of the known species' range. Caatinga howler monkey populations may also exist to the south of their known range or in the state of Maranhão (west of the known range). More surveys are urgently needed to understand their full distribution. Analysis of LEK in our study suggests that local people should be engaged in conservation strategies to help better understand species' geographic ranges.

We showed evidence that human population size, GDP, charcoal production, level of LEK and regional environmental characteristics may somehow effect Caatinga howler monkey distribution. For instance, the Ceará region had a larger human population than the Piauí region. This may have affected the distribution of the Caatinga howler monkeys in Ceará region, where only areas that are difficult to access (such as hilltops and areas with steep slopes) remain as suitable environments for Caatinga howler monkeys, potentially due to deforestation for agriculture and hunting pressure in other areas. Caatinga howler monkeys may not inhabit flatter areas in the Ceará region because of the type of vegetation available (Caatinga shrub vegetation IBGE 2004), tree cover loss and hunting pressure.

Both regions have experienced an increase in GDP over the last few years, but the Ceará region had a higher overall GDP than the Piauí region. GDP is an important factor to consider when preparing conservation strategies for Caatinga howler monkeys, because increasing GDP can be a strong driver for the expansion of urban areas, resulting in further habitat loss and a potential increase in hunting pressure. Surveys have shown a correlation between an increase in GDP and biodiversity loss (Czech 2008; Mcdonald et al. 2008; Seto et al. 2012) and a negative influence on Endangered species (Asafu-Adjaye 2003; Hoffman 2004). Additional studies are urgently needed to better understand factors influencing the Caatinga howler monkey distribution. Ethnographic data, for instance, would be critical in designing and implementing conservation measures as well as guiding research priorities (Burgman and Fox 2003; Gilchrist et al. 2005; Hill 2002; Rondinini et al. 2006) in the study areas.

The Piauí region produced more charcoal than the Ceará region. The municipality of São Miguel do Tapuio has a very large area, about $5207 \mathrm{~km}^{2}$, and is one of the largest charcoal production areas in the region. We 
recorded at least 4 groups of Caatinga howler monkeys in this municipality. Although there are large areas of natural vegetation there, most of these areas may be threatened by charcoal production. Caatinga howler monkey populations in the Piauí region depend on land owners and the local community to keep their habitat intact, since there are no protected areas in this region (MMA 2017). This highlights the importance of including the local community in the preservation of this Endangered species. North-central Piauí is an important area for the conservation of Caatinga howler monkeys because there are many populations and suitable habitats outside protected areas (Freire Filho and Palmeirim 2018 in press"). The establishment of national parks or other types of protected areas in both study regions might be beneficial. However, the creation of protected areas does not necessarily ensure wildlife protection in Brazil (e.g., Diniz and Brito 2015; Lessa et al. 2016) and monitoring of the Caatinga howler monkey habitats and populations would also be needed. Local community leaders should be involved in the construction of any protected areas to ensure sustainability and reduce conflicts that could pose risks to the local wildlife. Before the establishment of such protected areas, it is important to thoroughly understand how the boundaries of the areas affect local communities and propose alternatives to mitigate any potential impacts.

We found that the characteristics of the study regions may influence the level of LEK about our study species as well as the relationships between humans and the howler monkeys. More people knew of Caatinga howler monkeys in the Piauí region than in the Ceará region. Also, people in the Piauí region gave more detailed information about the species. Gilchrist et al. (2005) hypothesized that Local Ecological Knowledge should decline with increasing distance from both communities and travel routes, but this hypothesis has not been explicitly tested. In the Piauí region, Caatinga howler monkeys use canyons and areas with arboreal vegetation most frequently (Oliveira et al. 2007; Oliveira and Kierulff 2008). Canyons are very important areas in the driest period of the year for the primate species that inhabit the Serra da Capivara National Park in Piauí, since these are areas where water and food resources remain available (Moura 2007).

In the Piauí region we obtained reports of the death of Caatinga howler monkeys in the driest season of the year, potentially due to the lack of food and water resources characteristic of this season. This information coincides with what an 80-yearold man reported in the municipality of Uruoca in Ceará. He stated that a great drought in 1958 was responsible for the extinction of Caatinga howler monkeys in the region. This statement coincides with periods of great drought in Ceará state (Brabo Alves et al. 2004). Wild animals are an important protein source for several local communities, especially during the seasonal drought periods, when crops become scarce and domestic animals are decimated by starvation and thirst (da Silva Neto et al. 2017). Therefore, existing human pressures are likely to threaten species' persistence in the Caatinga (de Oliveira Araújo et al. 2012) and changes in climate could worsen the situation for the Caatinga's biodiversity (de Oliveira Araújo et al. 2012). However, climatic change essentially results from man's action on ecosystems that degrade very quickly but recover very slowly and lose biodiversity (da Silva 2004). In the Caatinga, a slight variation in temperature and 
precipitation (da Silva 2004) has an important role in the spatial patterns of its species richness (de Oliveira and Diniz-Filho 2011). Therefore, the climatic changes expected for future years, resulting from both human actions and natural phenomena in the biome, will be preponderant for the preservation of Caatinga howler monkeys.

In both Regions, people reported that Caatinga howler monkeys howl more frequently during the wettest period of the year. Some people said that they believed that Caatinga howler monkeys are responsible for bringing the rains and/or announcing that there will be rain in that particular year. Howl frequency is known to vary seasonally and according to the time of the day for some howler monkey species. For instance, researchers working on other howler monkey species have found that howling occurs most frequently in the early morning (Cunha and Jalles-Filho 2007; Sekulic 1982a,b; Whitehead 1989) as appears to be the case with Caatinga howler monkeys based on what the interviewees reported. Our direct observations and our interviewees also indicated that Caatinga howler monkeys howl frequently in the late hours of the afternoon. Colombian red howler monkeys ( $A$. seniculus) howl throughout the day during the rainy season, but they howl much more frequently in the early morning during the dry season, due to high temperatures during the day (Sekulic 1982a). Information on howling times and seasons may help guide future surveys of the species, increasing the chances of locating the species and optimizing researchers' time and use of funding. This information would also be important in contributing to further understanding the ecology and behavior of Caatinga howler monkeys during the driest and wettest period of the year, to determine how the species may react to future climate changes.

Many studies examine conflicted relationships between human and nonhuman primates (Hill 2000; Hill and Webber 2010). These conflicts are often caused by the expansion of agriculture (Madden 2004) and sometimes by difficulties in adapting to non-human primate species (Strum 1994). Poorly understood conflicts between humans and wildlife may represent one of the main problems for the creation of effective conservation and management strategies to promote the sustainability of human-wildlife interactions (Madden and McQuinn 2014; Setchell et al. 2017). The local communities included in our study generally maintained a harmonious relationship with Caatinga howler monkeys, although people reported poaching and medicinal uses of the Caatinga howler monkeys. The locals do not see Caatinga howler monkeys as a problem, possibly because Caatinga howler monkeys do not approach houses or feed on crops, unlike the Caatinga capuchin monkeys, who feed on crops and orchards near houses and are aggressive towards farmers (Freitas et al. 2008; Liebsch and Mikich 2015; Rocha et al. 2014). People see Caatinga capuchin monkeys as pests, and often kill or mob them (Rocha 2000; Rocha et al. 2014). These negative relationships reflect those between local residents and other capuchin species in other areas (Liebsch and Mikich 2015; Rocha 2000; Rocha et al. 2014). A better understanding of the motives behind local people's reactions to the presence of the capuchin monkeys will help conservationists to promote behavioral changes in the human population, and thus, create positive conservation outcomes. Establishing conflict-mitigation strategies that target problematic wildlife behaviors, such as crop-feeding, are particularly complicated and continuing research to 
understand these complex interactions may guide effective land-use plans (Hockings and Sousa 2013; Wittmer et al. 2006; Woodroffe et al. 2005).

Despite the overall peaceful relationship between Caatinga howler monkeys and the local human population, the report of the medicinal use of Caatinga howler monkeys in Piauí region is a critical interaction to highlight. This has also been reported elsewhere in the Northern region of Piauí State (Pinto and Roberto 2011). The medicinal use of several groups of animals is part of Brazilian culture (Alves and Santana 2008; Costa-Neto and Marques 2000; Ferreira et al. 2012; Silva 2008; Souto et al. 2011). Alouatta belzebul is used as medicine for whooping cough, sore throats and asthma (Alves et al. 2010). Their hyoid bone is filled with water and used as a cup (Alves et al. 2007). Nevertheless, hunting and trafficking of endangered animals such as Caatinga howler monkeys for any reason is prohibited by Brazilian law and the penalties for such crimes include spending six months to one year in jail and the payment of $R \$ 500$ per specimen. The fine can rise to $R \$ 5000$ if it is an Endangered species (Art. 29 da Lei Federal 9605/98 - Lei de Crimes Ambientais). However, the authorities' oversight of hunting and trafficking of endangered animals means that locals often engage in such activities. The knowledge of these penalties may have influenced the responses given by the locals in our interviews, with reports of hunting and illegal trafficking potentially being underestimated. Further research is needed to better understand exactly how the monkeys are used as medicine and for what purposes and the cultural significance of using Caatinga howler monkeys. We also need to understand in what circumstances locals would turn to an alternative treatment and whether a replacement treatment would be readily available and affordable. These are ethical issues to be considered.

GDP and/or the characteristics of each region influenced the relationship between primates and the local human communities in the study regions. These factors may also be responsible for the different distribution patterns of the Caatinga howler monkey in the two study regions. Conflict over land use is often associated with studies of humannonhuman primate interactions (Fuentes 2006). However, Caatinga howler monkeys are part of a genus of Neotropical primates that tolerates a certain degree of anthropogenic disturbance (Bicca-Marques 2003; Crockett 1998; Horwich 1998). In some municipalities in the Piauí region, Caatinga howler monkey groups come within $10 \mathrm{~m}$ of local houses. Nevertheless, in these municipalities, we found no evidence in our interviews and direct observations that the animals were hunted. In contrast, anthropogenic disturbances in other areas in both study regions may stimulate or facilitate poaching, with Caatinga howler monkeys being an easy target because of their calm behavior and evident vocalization. Further studies are needed to elucidate the degree of anthropogenic pressure on Caatinga howler monkeys in both regions and to understand how they interact with humanmade habitats.

We hope our study can be used to generate effective management and conservation strategies to help the preservation of this poorly known and highly threatened primate species. LEK has proven to be a useful, relatively inexpensive and less time consuming tool to obtain important data on Caatinga howler monkeys. Through LEK we obtained some basic information about the ecology of this poorly known species (e.g., diet, vocalization pattern, 
social behaviors, population fluctuation and seasonality). Nevertheless, additional studies are certainly still needed to elucidate the total geographic range, behavioral ecology patterns and natural history of the species. Such information would be better acquired by direct observations of the animals in systematic and long-term studies. Despite the harmonious relationship between locals and Caatinga howler monkeys, the use of environmental education as a tool for raising conservation awareness will be essential for the survival of this Endangered primate. Such education environmental approaches should focus on creating awareness to reduce hunting and deforestation of the Caatinga howler monkey habitat.

\section{ACKNOWLEDGEMENTS}

The study was funded by a Rufford small grant (Grant number: 19646-1). RFF is currently funded by a FACEPE scholarship (IBPG-1236-2.05/16). We specially thank Cágados and Aiuá local communities for their support and friendly welcome. We are thankful to Andressa Fraga and Nádia Freitas for assistance in the field. We also thank Professor Carla Soraia Soares de Castro for discussions on earlier stages of this study. Moreover, we thank Marcos Fialho and Leandro Jerusalinsky (CPBICMBio members) for providing additional information on the potential presence of the species in some sites. We thank Ms. Rebecca Umeed for grammar revision of this manuscript.

\section{REFERENCES}

Alvares CA, Stape JL, Sentelhas PC, Gonçalves JLM, Sparovek G (2013) Koppen's climate classification map for Brazil. Meteorologische Zeitschrift 22:711-728.
Alves RRN, Feijó A, Barboza RRD, Souto WMS, Fernandes-Ferreira $\mathrm{H}$, Cordeiro-Estrela $\mathrm{P}$, Langguth A (2016) Game mammals of the Caatinga biome. Ethnobiology and Conservation 5:1-51.

Alves RRN, Rosa IL, Santana GG (2007) The role of animal-derived remedies as complementary medicine in Brazil. Bioscience 57:949-955.

Alves RRN, Santana GG (2008) Use and commercialization of Podocnemis expansa (Schweiger 1812) (Testudines: Podocnemididae) for medicinal purposes in two communities in North of Brazil. Journal of Ethnobiology and Ethnomedicine 4:1-6.

Alves, RRN, Souto, W, Barboza, RR (2010) Primates in traditional folk medicine: a world overview. Mammal Review 40:155-180.

Anadón JD, Giménez A, Ballestar R, Pérez I (2009) Evaluation of local ecological knowledge as a method for collecting extensive data on animal abundance. Conservation Biology 23:617-625.

Anadón JD, Giménez A, Ballestar R (2010) Linking local ecological knowledge and habitat modelling to predict absolute species abundance on large scales. Biodiversity and Conservation 19:1443-1454.

Andrade Júnior AS, Bastos EA, Silva CO, Gomes AAN, Figueredo Júnior LGM (2004) Atlas climatológico do Estado do Piauí. 1 ed. Embrapa Meio-Norte, Teresina, PI, Brasil.

Asafu-Adjaye J (2003) Biodiversity loss and economic growth: a cross-country analysis. Contemporary Economic Policy 21:173-185.

Aswani S, Lemahieu A, Sauer WH (2018) Global trends of local ecological knowledge and future implications. PloS One 13:e0195440.

Bicca-Marques JC (2003) How do howler cope with habitat fragmentation?. In: Marsh MK (ed.), Primates in fragments: ecology and conservation. 1 ed. Kluwer Academic/Plenum, New York, pp. 283-303.

Bicca-Marques JC, Silva VM, Gomes DF (2006) Ordem Primates. In: Cheida CC, NakanoOliveira E, Fusco-Costa R, Rocha-Mendes F, Quadros J (eds.) Mamíferos do Brasil. 1 ed. Sociedade Brasileira de Zoologia, Londrina, pp. 101-148. 
Bonvicino CR, Langguth A, Mittermeier RA (1989) A study of the pelage color and geographic distribution in Alouatta belzebul (Primates: Cebidae). Revista Nordestina de Biologia 6:139-148.

Brabo Alves JM, Silva RA, Souza EB, Repelli CA (2004) Principais secas ocorridas neste século no estado do Ceará: uma avaliação pluviométrica.[http://www.cbmet.com/cbmfiles/1 3-1380726e80520f5fb2161d562051b1ad.pdf.] Accessed 30 March 2017.

Burgman MA, Fox JC (2003) Bias in species range estimates from minimum convex polygons: implications for conservation and options for improved planning. Animal Conservation 6:19-28.

Castellanos-Galindo GA, Cantera JR, Espinosa S, Mejía-Ladino LM (2011) Use of local ecological knowledge, scientist's observations and grey literature to assess marine species at risk in a tropical eastern Pacific estuary. Aquatic Conservation: Marine and Freshwater Ecosystems 21:37-48.

Ceballos-Mago N, Chivers DJ (2010) Local knowledge and perceptions of pet primates and wild Margarita capuchins on Isla de Margarita and Isla de Coche in Venezuela. Endangered Species Research 13:63-72.

Costa-Neto EM, Marques JGW (2000) Faunistic resources used as medicines by artisanal fishermen from Siribinha beach, State of Bahia, Brazil. Journal of Ethnobiology 20:93109.

Crockett CM (1998) Conservation biology of the genus Alouatta. International Journal of Primatology 19:549-578.

Cullen LC, Pretty J, Smith D, Pilgrim SE (2007) Links between local ecological knowledge and wealth in indigenous communities of Indonesia: Implications for conservation of marine resources. The International Journal of Interdisciplinary Social Sciences 2:289-299.

Cunha RGT, Jalles-Filho E (2007) The roaring of southern brown howler monkeys (Alouatta guariba clamitans) as a mechanism of active defense of borders. Folia Primatologica 78:259271.

Czech B (2008) Prospects for reconciling the conflict between economic growth and biodiversity conservation with technological progress. Conservation Biology 22:1389-1398.
Czech B, Pister P (2005) Economic growth, fish conservation, and the American fisheries society. Fisheries 30:38-10.

da Silva Neto BC, do Nascimento ALB, Schiel N, Alves RRN, Souto A, Albuquerque UP (2017) Assessment of the hunting of mammals using local ecological knowledge: an example from the Brazilian semiarid region. Environment, Development and Sustainability 19:1795-1813.

da Silva VDPR (2004) On climate variability in Northeast of Brazil. Journal of Arid Environments 58:575-596.

Davis A, Wagner JR (2003) Who knows? On the importance of identifying "experts" when researching local ecological knowledge. Human Ecology 31:463-489.

de Oliveira G, Araújo MB, Rangel TF, Alagador D, Diniz-Filho JAF (2012) Conserving the Brazilian semiarid (Caatinga) biome under climate change. Biodiversity and Conservation 21:2913-2926

de Oliveira G, Diniz-Filho JAF (2011) Evaluating environmental and geometrical constraints on endemic vertebrates of the semiarid Caatinga (Brazil). Basic and Applied Ecology 12:664-673.

Diniz MF, Brito D (2015) Protected areas effectiveness in maintaining viable giant anteater (Myrmecophaga tridactyla) populations in an agricultural frontier. Natureza \& Conservação 13:145-151.

Dore KM, Riley EP, Fuentes A (2017) Ethnoprimatology: A practical guide to research at the human-nonhuman interface. Cambridge University Press, Cambridge, UK.

Drummond JA, Franco JLA, Ninis AB (2009) Brazilian federal conservation units: a historical overview of their creation and of their current status. Environment and History 15:463-491.

Estrada A (2006) Human and non-human primate co-existence in the Neotropics: a preliminary view of some agricultural practices as a complement for primate conservation. Ecological Environmental Anthropology 2:17-29.

Ferreira FS, Albuquerque UP, Coutinho HDM, Almeida WO, Alves RRN (2012) The trade in medicinal animals in Northeastern Brazil. Evidence-Based Complementary and Alternative Medicine 2012:1-20. 
Ferreira, JG, Pinto T, Fialho MS, Laroque PO (2016) Avaliação do risco de extinção de Alouatta ululata Elliot, 1912 no Brasil, Ministério do Meio Ambiente. [http://www.icmbio.gov.br/portal/faunabrasileira/e stado-de-conservacao/7188-mamiferos-alouattaululata-guariba] Accessed 22 June 2016.

Freitas CHD, Setz EZ, Araújo AR, Gobbi N (2008) Agricultural crops in the diet of bearded capuchin monkeys, Cebus libidinosus Spix (Primates: Cebidae), in forest fragments in southeast Brazil. Revista Brasileira de Zoologia 25:32-39.

Freire Filho R, Palmeirim JM (2018) Potential distribution and priority conservation areas for the endangered Caatinga Howler Monkey Alouatta ululata, Northeastern Brazil. Oryx in press.

Fuentes A (2006) Human-nonhuman primate interconnections and their relevance to anthropology. Ecological and Environmental Anthropology 2:1-11.

Fuentes A, Cortez AD, Peterson JV (2016) Ethnoprimatology and Conservation: applying insights and developing practice. In: Waller MT (ed.) Ethnoprimatology: Primate conservation in the 21st Century. Springer International Publishing, Bend, pp.1-19.

Fuentes A, Hockings KJ (2010) The ethnoprimatological approach in primatology. American Journal of Primatology 72:841-847.

Gadgil M, Berkes F, Folke C (1993). Indigenous knowledge for biodiversity conservation. Ambio 22:151-156.

Gilchrist G, Mallory M, Merkel F (2005) Can local ecological knowledge contribute to wildlife management? Case studies of migratory birds. Ecology and Society 10:20.

Gomes AAN, Andrade Júnior AS, Medeiros RM (2005) Evapotranspiração de referência mensal para o Estado do Piauí. Revista Brasileira de Engenharia Agrícola e Ambiental 9:560-564.

Gómez-Baggethun E, Corbera E, Reyes-García V (2013) Traditional ecological knowledge and global environmental change: research findings and policy implications. Ecology and Society: a journal of integrative science for resilience and sustainability 18:1-8.
Gray TN, Phommachak A, Vannachomchan K, Guegan F (2017) Using local ecological knowledge to monitor threatened Mekong megafauna in Lao PDR. Plos One 12:e0183247.

Gregorin R (2006) Taxonomia e variação geográfica das espécies do gênero Alouatta Lacépède (Primates, Atelidae) no Brasil. Revista Brasileira de Zoologia 23:64-144.

Guedes PG, Borges-Nojosa DM, Silva JAG, Salles LO (2000) Novos registros de Alouatta no estado do ceará (Primates, atelidae). Neotropical Primates 8:29-30.

Gutiérrez E, Marinho-Filho J (2017) The mammalian faunas endemic to the Cerrado and the Caatinga. ZooKeys 644:105-157.

Haenn N, Schmook B, Reyes YM, Calmé S (2014) A cultural consensus regarding the king vulture?: preliminary findings and their application to Mexican conservation. Ethnobiology and Conservation 3:1-15.

Hill CM (2000) Conflict of interest between people and baboons: Crop raiding in Uganda. International Journal of Primatology 21:299-315.

Hill CM (2002) Primate conservation and local communities - ethical issues and debates. American Anthropologist 104:1184-1194.

Hill CM, Webber AD (2010) Perceptions of nonhuman primates in human-wildlife conflict scenarios. American Journal of Primatology 72:919-924.

Hockings KJ, Sousa C (2013) Humanchimpanzee sympatry and interactions in Cantanhez National Park, Guinea-Bissau: current research and future directions. Primate Conservation 26:57-65.

Hoffman JP (2004) Social and environmental influences on endangered species: a crossnational study. Sociological Perspectives 47:79107.

Horwich RH (1998) Effective solutions for howler conservation. International Journal of Primatology 19:579-598.

Huntington HP (2000) Using traditional ecological knowledge in science: methods and applications. Ecological Applications 10:1270-1274.

IBGE

Vegetação. [http://mapas.ibge.gov.br/tematicos/vegetacao.ht ml.] Accessed 17 April 2017. 
Leal IR, Silva JMC, Tabarelli M, Lacher TE (2005) Changing the course of biodiversity conservation in the caatinga of northeastern Brazil. Conservation Biology 19:701-706.

Lessa I, Guimarães TCS, de Godoy Bergallo H, Cunha A, Vieira EM (2016). Domestic dogs in protected areas: a threat to Brazilian mammals?. Natureza \& Conservação 14:46-56.

Liebsch D, Mikich SB (2015) First record of Eucalyptus spp. bark-stripping by browncapuchin monkeys (Sapajus nigritus, PRIMATES: CEBIDAE). Ciência Florestal 25:501-505

López-Arévalo HF, Gallina S, Landgrave R, Martínez-Meyer E, Muñoz-Villers LE (2011) Local knowledge and species distribution models' contribution towards mammalian conservation. Biological Conservation 144:1451-1463.

Lunney D, Curtin A, Ayers D, Cogger HG, Dickman CR (1995) An ecological approach to identifying the endangered fauna of New South Wales. Pacific Conservation Biology 2:212-231.

Madden F (2004) Creating coexistence between humans and wildlife: global perspectives on local efforts to address human-wildlife conflict. Human Dimensions of Wildlife 9:247-257.

Madden F, McQuinn B (2014) Conservation's blind spot: the case for conflict transformation in wildlife conservation. Biological Conservation 178:97-106.

Mcdonald RI, Kareiva P, Forman RTT (2008) The implications of current and future urbanization for global protected areas and biodiversity conservation. Biological Conservation 141:1695-1703.

McPherson J, Sammy J, Sheppard D, Mason J, Brichieri-Colombi T, Moehrenschlager A (2016) Integrating traditional knowledge when it appears to conflict with conservation: lessons from the discovery and protection of sitatunga in Ghana. Ecology and Society 21: 24.

MMA (2016) Sistema Nacional de Unidades Conservação SNUC.

[http://www.mma.gov.br/areasprotegidas/sistema-nacional-de-ucs-snuc.] Accessed 22 April 2017.
MMA

(2017)

Dados

Georreferenciados.[http://www.mma.gov.br/area s-protegidas/cadastro-nacional-de-ucs/dadosgeorreferenciados.] Accessed 22 April 2017.

Moller H, Berkes F, Lyver POB, Kislalioglu M (2004) Combining science and traditional ecological knowledge: monitoring populations for co-management. Ecology and Society 9: 2 .

Moro MF, Lughadha EN, Araújo FS, Martins FR (2016) A Phytogeographical metaanalysis of the semiarid Caatinga domain in Brazil. Botanical Review 82: 91-148.

Moura ACA (2007) Primate group size and abundance in the Caatinga dry forest, northeastern Brazil. International Journal of Primatology 28: 1279-1297.

Newton P, Van Thai N, Roberton S, Bell D (2008) Pangolins in peril: using local hunters' knowledge to conserve elusive species in Vietnam. Endangered Species Research 6:4153.

Oliveira MM, Ferreira JG, Mota GLS, Soares SG (2007) Mapeamento das áreas de ocorrência de Alouatta ululata-Etapa Ceará. In: BiccaMarques, JC (ed.), A Primatologia do Brasil. Sociedade Brasileira de Primatologia, Porto Alegre, pp. 151- 161.

Oliveira MM, Kierulff, MCM (2008) Alouatta ululata. The IUCN Red List of Threatened Species 2008: e.T918A13094890. [http://dx.doi.org/10.2305/IUCN.UK.2008.RLTS.T 918A13094890.en.] Accessed 24 May 2016.

Olsson P, Folke C (2001) Local ecological knowledge and institutional dynamics for ecosystem management: a study of Lake Racken watershed, Sweden. Ecosystems 4:85104.

Pandey DN (2003) Cultural resources for conservation science. Conservation Biology 17:633-635.

Pretty J, Smith DJ (2004) Social capital in biodiversity conservation and management. Conservation Biology 18:631-638.

Pilgrim SE, Cullen LC, Smith DJ, Pretty J (2008) Ecological knowledge is lost in wealthier communities and countries. Environmental Science \& Technology 42:1004-1009. 
Pinto T, Roberto IJ (2011) Conservation of the caatinga howler monkey, Brazil. Final report. [http://www.conservationleadershipprogramme.or g/media/2014/11/080209_Brazil_FinalReport_Ho wler-Monkey.pdf.] Accessed 24 May 2017.

QGIS Development Team (2016). QGIS training manual. Open Source Geospatial Foundation Project.

[http://docs.qgis.org/2.14/en/docs/training_manu al/index.html.] Accessed 29 May 2016.

Riedlinger D, Berkes F (2001) Contributions of traditional knowledge to understanding climate change in the Canadian Arctic. Polar Record 37:315-328.

Riley EP (2006) Ethnoprimatology: toward reconciliation of biological and cultural anthropology. Ecological and Environmental Anthropology 2:75-86.

Rocha VJ (2000) Macaco-Prego, como controlar esta nova praga florestal?. Floresta 30:95-99.

Rocha LC, Sobroza TV, Campos ACA, Marafiga A, Fortes VB (2014) Percepções e atitudes de moradores rurais em relação ao macacoprego, Sapajus nigritus (Goldfuss, 1809), na área de influência da Usina Hidrelétrica Dona Francisca: contexto local e perspectivas para a solução dos conflitos. In: Passos FC, Miranda JMD (eds.), A Primatologia no Brasil. Sociedade Brasileira de Primatologia, Curitiba, pp. 137-151.

Rondinini C, Wilson, KA, Boitani L, Grantham H, Possingham HP (2006) Tradeoffs of different types of species occurrence data for use in systematic conservation planning. Ecology Letters 9:1136-1145.

Sekulic R (1982a) Daily and seasonal patterns of roaring and spacing in four red howler Alouatta seniculus trops. Folia Primatologica 39:22-48

Sekulic R (1982b) The function of howling in red howler monkeys (Alouatta seniculus). Behaviour 81:38-54.

Setchell JM, Fairet E, Shutt K, Waters S, Bell S (2017) Biosocial conservation: Integrating biological and ethnographic methods to study human-primate interactions. International Journal of Primatology 38:401-426.

Seto KC, Güneralp B, Hutyra LR (2012) Global forecasts of urban expansion to 2030 and direct impacts on biodiversity and carbon pools. Proceedings of the National Academy of Sciences 109:16083-16088.
Silva AL (2008) Animais medicinais: conhecimento e uso entre as populações ribeirinhas do rio Negro, Amazonas, Brasil. Boletim do Museu Paraense Emílio Goeldi 3:343-357.

Silvano RAM, Silva AL, Ceroni M, Begossi A (2008) Contributions of ethnobiology to the conservation of tropical rivers and streams. Aquatic Conservation: Marine and Freshwater Ecosystems 18:241-260.

Souto WMS, Mourão JS, Barboza RRD, Mendonça LET, Lucena RFP, Confessor MVA, Vieira WLS, Montenegro PFGP, Alves RRN (2011) Medicinal animals used in ethnoveterinary practices of the "Cariri Paraibano", NE Brazil. Journal of Ethnobiology and Ethnomedicine 7:1-19.

Souza MJN, Oliveira VPV (2006) Os enclaves úmidos e sub-úmidos do semi-árido do nordeste brasileiro. Mercator 5:85-102.

Stafford CA, Alarcon-Valenzuela J, Patiño J, Preziosi RF, Sellers WI (2016) Know your monkey: identifying primate conservation challenges in an indigenous Kichwa community using an ethnoprimatological approach. Folia Primatologica 87:31-47.

Starr C, Nekaris KAI, Streicher U, Leung LKP (2011) Field surveys of the Vulnerable pygmy slow loris Nycticebus pygmaeus using local knowledge in Mondulkiri Province, Cambodia. Oryx 45:135-142.

Strum SC (1994) Prospects for management of primate pests. Revue d Ecologie (Terre Vie) 49:295-306.

Tabarelli M, Santos AMM (2004) Uma breve descrição sobre a história natural dos Brejos nordestinos. In: Pôrto KC, Cabral JJP, Tabarelli $M$ (eds.) Brejos de altitude em Pernambuco e Paraíba: história natural, ecologia e conservação. Ministério do Meio Ambiente, Brasilia, pp.17-24.

Tang R, Gavin MC (2016) A classification of threats to traditional ecological knowledge and conservation responses. Conservation and Society 14:57-70.

Toledo V (2002) Ethnoecology: A Conceptual Framework for the Study of Indigenous Knowledge of Nature. In: Stepp JR, Wyndham FS, Zarger RK (eds.) Ethnobiology and Biocultural Diversity. University of Georgia Press, Athens, pp.511-523. 
Torres Junior EU, Valença-Montenegro MM, Castro CSS (2016) Local ecological knowledge about endangered primates in a rural community in Paraíba, Brazil. Folia Primatologica 87:262-277.

Vaughan N, Lucas E, Harris S, White PL (2003) Habitat associations of European hares Lepus europaeus in England and Wales: implications for farmland management. Journal of Applied Ecology 40:163-175.

Veiga GV, Cunha AS, Sichieri R (2004) Trends in overweight among adolescents living in the poorest and richest regions of Brazil. American Journal of Public Health 94:1544-1548.

Viana MC, Bonvicino CR, Ferreira JG, Jerusalinsky L, Langguth A, Seuánez H (2015) Understanding the relationship between Alouatta ululata and Alouatta belzebul (Primates: Atelidae) based on cytogenetics and molecular phylogeny. Oecologia Australis 19:173-182.
Whitehead JM (1989) The effect of the location of a simulated intruder on responses to longdistance vocalizations of mantled howling monkeys, Alouatta palliata palliata. Behaviour 108:73-103.

Wittmer H, Rauschmayer F, Klauer B (2006) How to select instruments for the resolution of environmental conflicts?. Land use Policy 23:1-9.

Woodroffe R, Thirgood S, Rabinowitz A (2005) People and wildlife, conflict or coexistence?. Cambridge University Press, Cambridge, UK.
Received: 24 January 2018

Accepted: 07 August 2018

Published: 28 August 2017 